\title{
Thực trạng thị trường nhà ở đô thị cho người thu nhập trung bình tại thành phố Hồ Chí Minh
}

\section{Urban housing market for moderate income households in Ho Chi Minh City}

\author{
Lê Minh Phương Mai ${ }^{1 *}$
}

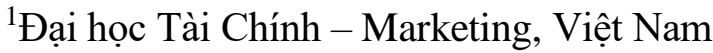

*Tác giả liên hệ, Email: phuongmai@ufm.edu.vn

THÔNG TIN

DOI: $10.46223 / \mathrm{HCMCOUJS.}$ proc.vi.16.1.1858.2021

Ngày nhận: 7/3/2021

Ngày nhận lại: 31/3/2021

Duyệt đăng: 9/4/2021

Tù khóa:

nhà ở xã hội, nhà ở đô thị, người thu nhập trung bình

Keywords:

Social houses, urban houses, moderate- income households
TÓM TÁT
Bài nghiên cứu trình bày thực trạng nhà ở đô thị cho người thu nhập trung bình thông qua việc tóm tắt các chương trình phát triển nhà ở, các giai đoạn phát triển thị trường nhà ở đô thị, các hệ thống văn bản liên quan đến nhà ở xã hội, thực trạng nguồn cung và nhu cầu nhà ở đô thị cho người thu nhập trung bình. Những vấn đề thực trạng thị trường nhà ở phân khúc này gặp phải. Từ đó tác giả đề xuất một số kiến nghị nhằm hỗ trợ sự phát triển của thị trường nhà ở đô thị cho người thu nhập trung bình.

\section{Giới thiệu}

Nhà ở là nhu cầu cần thiết trong cuộc sống của con người tuy nhiên giá nhà ngày càng tăng, đã tạo khoảng cách giữa nhóm thu nhập cao và nhóm thu nhập thấp trong việc sở hữu về nhà ở. Đối với nhóm người thu nhập thấp và trung bình, sở hữu một ngôi nhà trở thành giấc mơ khó thực hiện được. Tại Việt Nam, trong những năm qua, Chính phủ chú trọng phát triển chủ yếu các loại hình nhà ở cho người thu nhập thấp, nhà ở xã hội. Khi Luật đất đai năm 1993 và Luật Kinh doanh Bất động sản năm 2006 ra đời, đã mở ra cơ sở pháp lý để phát triển thị trường bất động sản. Tuy nhiên, thị trường bất động sản chủ yếu do những người có thu nhập cao nắm giữ hoặc giá nhà quá cao vượt tầm với của người có thu nhập thấp và trung bình. Tại Đại hội đại biểu Đảng bộ thành phố Hồ Chí Minh lần thứ X đã đề ra Chương trình đột phá thứ 7 "Churong trình chỉnh trang và phát triển đô thị”, trong đó có chương trình xây dựng, nâng cấp các chung cư cũ; Chương trình di dời, tái định cư nhà trên và ven kênh rạch; Chương trình phát triển nhà ở xã hội, khu lưu trú công nhân, ký túc xá sinh viên. Ủy ban nhân dân thành phố và các Sở, ngành, 
quận, huyện cũng đã đề ra chương trình hành động để tổ chức thực hiện. Đây là các chương trình động lực tạo điều kiện để thực hiện xã hội hóa, huy động nguồn lực của các doanh nghiệp tích cực tham gia xây dựng, chỉnh trang và phát triển đô thị thành phố Hồ Chí Minh có chất lượng sống tốt theo phương thức xây dựng - chuyển giao (BT), hoặc hợp tác công tư (PPP). Trong đó, có mục tiêu phát triển nhà ở xã hội, nhà ở tái định cư, nhà ở thương mại giá rẻ để bán, bán trả góp dài hạn, cho thuê cho người có thu nhập trung bình, người có thu nhập thấp, cán bộ, chiến sĩ lực lượng vũ trang, công nhân, lao động và người nhập cư.

\section{Chương trình phát triển nhà ở trọng điểm hiện nay và cụ thể chương trình nhà ở xã hội}

\subsection{Các chương trình phát triển nhà ở trọng điểm hiện nay}

Các chương trình phát triển nhà ở hiện nay của thành phố Hồ Chí Minh có thể kể đến là: chương trình nhà ở xã hội, chương trình cải tạo chung cư hư hỏng, chương trình giải tỏa nhà ven kênh, rạch, chương trình tái định cư.

\section{Bảng 1}

Tiến độ thực hiện nhà ở cho cán bộ, công nhân viên chức, lực lượng vũ trang và nhà ở cho người thu nhập thấp đến năm 2015

\begin{tabular}{|l|c|c|c|c|c|c|c|}
\hline & Trước 2010 & $\mathbf{2 0 1 1}$ & $\mathbf{2 0 1 2}$ & $\mathbf{2 0 1 3}$ & $\mathbf{2 0 1 4}$ & $\mathbf{2 0 1 5}$ & Tổng \\
\hline Nhà ở CB CNV & 46 & 0 & 0 & 0 & 0 & 0 & 46 \\
\hline Nhà ở xã hội & 2 & 1 & 1 & 4 & 0 & 4 & 12 \\
\hline Nhà ở cho lực lượng vũ trang & 0 & 2 & 2 & 1 & 0 & 1 & 6 \\
\hline Tổng cộng & 48 & 3 & 3 & 5 & 0 & 5 & 64 \\
\hline
\end{tabular}

Nguồn: Sở xây dựng Thành phố Hồ Chí Minh, Đại học Việt Đức (2018)

\subsection{Khái niệm và hệ thống văn bản liên quan chương trình nhà ở xã hội}

Hiện nay, hệ thống văn bản pháp luật về bất động sản của Việt Nam chưa có thuật ngữ nhà ở cho người thu nhập trung bình, mà chỉ có thuật ngữ nhà ở xã hội. Trước năm 2000, nhà nước giữ vai trò chủ đạo trong việc cung cấp nhà ở cho các đối tượng ưu tiên và muốn hướng các thành phần kinh tế khác tham gia vào phân khúc này.

Đầu năm 2000, khái niệm nhà ở ưu đãi, được đề cập trong nghị định 71/2001/NĐ-CP của chính phủ về ưu đãi đầu tư xây dựng nhà ở bán và cho thuê. Đây là nền tảng đầu tiên của thuật ngữ nhà ở xã hội. Trong nghị định nêu rõ, các chung cư cao tầng phải ưu tiên bán và cho thuê những đối tượng như cán bộ, công nhân, viên chức nhà nước và sinh viên.

Khái niệm nhà ở xã hội xuất hiện gián tiếp trong Chiến lược phát triển nhà ở quốc gia được ban hành theo quyết định 76/2004/QĐ-TTg thông qua việc định nghĩa Quỹ nhà ở xã hội. Năm 2005, khái niệm Nhà ở xã hội chính thức xuất hiện trong Luật nhà ở 2005 với định nghĩa Nhà ở xã hội là: "Nhà ở do Nhà nước hoặc tổ chức, cá nhân đầu tư xây dựng để cho các đối tượng quy định tại điều 53 và điều 54 của Luật định này thuê hoặc thuê mua". Theo đó, quy định nhà ở xã hội phải là nhà chung cư và các thành phần kinh tế cùng tham gia xây dựng. "Đối tượng được hưởng chính sách nhà ở xã hội bao gồm 3 nhóm: cán bộ công chức, lực lượng vũ trang, công nhân khu công nghiệp" và "phải đáp ứng đủ 3 điều kiện: chưa sở hữu nhà, nếu có thì diện tích nhỏ hơn $5 \mathrm{~m}^{2} /$ người và nhà bị dột nát hư hỏng, sẽ được hưởng chính sách cho thuê"

Năm 2006, nghị định 90/2006/NĐ-CP ngày 09/06/2006 quy định chi tiết và hướng dẫn 
thi hành Luật nhà ở đã quy định “có 4 nhóm đối tượng hưởng chính sách nhà ở xã hội dưới dạng thuê và thuê mua", có bổ sung thêm nhóm "nhà ở công vụ"

Năm 2009, quyết định số 67/2009/QĐ-TTg ngày 24/4/2009 về cơ chế chính sách phát triển nhà ở cho người thu nhập thấp quy định ngoài việc đáp ứng đủ 3 điều kiện trong luật nhà ở, đã bổ sung thêm 2 điều kiện là chưa hưởng chính sách và thường trú hoặc tạm trú dài hạn, sẽ được thuê, thuê mua, hoặc trả tiền một lần.

Năm 2010, nghị định 71/2010/NĐ-CP ngày 23/6/2010 đã quy định tăng lên 6 nhóm đối tượng, bổ sung "loại nhà ở xã hội do Nhà nước đầu tư xây dựng bằng vốn ngân sách nhà nước để cho thuê", còn lại nhà ở xã hội xây dựng không phải từ vốn ngân sách nhà nước sẽ được bán, cho thuê, cho thuê mua. Ngoài ra, có bổ sung thêm quy định thanh toán trước $20 \%$ giá trị thuê mua.

Thông tư số 16/2010/TT-BXD ngày 01/09/2010 hướng dẫn thực hiện Nghị định 71/2010/NĐ-CP quy định “các đối tượng thuê nhà ở xã hội phải có mức thu nhập bình quân hang tháng không thuộc diện nộp thuế thu nhập cá nhân từ thu nhập thường xuyên theo quy định của pháp luật về Thuế thu nhập cá nhân".

Năm 2013 và 2014, thông tư 07/2013/TT- BXD ngày 15/5/2013 của Bộ xây dựng hướng dẫn việc xác định đối tượng được vay vốn hỗ trợ nhà ở. Nghị định 188/2013 và thông tư hướng dẫn số 08/2014/TT-BXD ngày 23/5/2014 có bổ sung thêm về phía cung nhà ở xã hội là hộ gia đình, cá nhân được quyền đầu tư xây dựng nhà ở xã hội để bán, cho thuê, đồng thời tang lên đến 10 nhóm được hưởng chính sách nhà ở xã hội.

Năm 2014, Luật nhà ở số 65/2014/QH13 định nghĩa "nhà ở xã hội là nhà ở có sự hỗ trợ của nhà nước cho các đối tượng được hưởng chính sách hỗ trợ về nhà ở theo quy định của Luật này tại điều 49", quy định 8 nhóm đối tượng hưởng chính sách mua, thuê nhà ở xã hội và 2 nhóm đối tượng chỉ hưởng chính sách hỗ trợ.

Có thể thấy, chính sách về nhà xã hội đã được điều chỉnh nhiều lần trong những năm qua để đáp ứng nhu cầu thực tế, nhưng vẫn chưa giải quyết được vấn đề nhà ở cho người thu nhập thấp và trung bình. Các đối tượng được hưởng chính sách hỗ trợ về nhà ở được mở rộng. Tuy nhiên, quy chuẩn, hướng dẫn thiết kế, xây dựng, quản lý về nhà ở xã hội vẫn chưa được ban hành, gây lúng túng torng công tác đầu tư xây dựng và quản lý, đặc biệt là cho các đối tượng nhà đầu tư tư nhân.

\section{Hồ Chí Minh}

\subsection{Tình hình thị trưòng nhà ở đô thị cho người thu nhập trung bình tại thành phố}

Các giai đoạn phát triển đô thị Thành phố Hồ Chí Minh

\begin{tabular}{|c|c|c|c|c|}
\hline $\begin{array}{l}\text { Phục hồi kinh } \\
\text { tế sau chiến } \\
\text { tranh }\end{array}$ & $\begin{array}{l}\text { Bắt đầu giai } \\
\text { đoạn đổi mới }\end{array}$ & $\begin{array}{l}\text { Quy hoạch tổng } \\
\text { thể xây dựng } \\
\text { TP.HCM }\end{array}$ & $\begin{array}{c}\text { Điều chỉnh quy hoạch } \\
\text { chung TP.HCM đến } \\
\text { năm } 2020\end{array}$ & $\begin{array}{c}\text { Điều chỉnh Quy hoạch } \\
\text { chung TP.HCM đến } \\
\text { năm } 2025\end{array}$ \\
\hline 1976 & 1986 & 93 & 1998 & 2010 \\
\hline $\begin{array}{l}\text { Thành phố chú } \\
\text { trọng phục hồi } \\
\text { kinh tế sau } \\
\text { chiến tranh, các } \\
\text { hoạt động phát } \\
\text { triển đô thị diễn } \\
\text { ra chậm chạp }\end{array}$ & $\begin{array}{l}\text { Dòng người } \\
\text { nhập cư từ đồng } \\
\text { bằng song Cửu } \\
\text { Long, khu } 4 \text { và } \\
\text { duyên hải miền } \\
\text { Trung, TP phát } \\
\text { triển lan tỏa }\end{array}$ & $\begin{array}{l}\text { Hàng loạt khi Công } \\
\text { nghiệp, Khu chế xuất ra } \\
\text { đời, nhà ở tự phát và } \\
\text { nhiều khu dân cư mới } \\
\text { được xây dựng, nhiều } \\
\text { công trình có quy mô lớn } \\
\text { làm thay đồi diện mạo } \\
\text { kiến trúc khu trung tâm }\end{array}$ & $\begin{array}{l}\text { Đô thị hóa diễn ra nhanh } \\
\text { chóng. Các dự án đầu tư } \\
\text { bất động sản xuất hiện ở } \\
\text { nhiều nơi. Các dự án đầu } \\
\text { tư cơ sở hạ tầng giao } \\
\text { thông và cải tạo môi } \\
\text { trường được quan tâm } \\
\text { phát triển }\end{array}$ & $\begin{array}{l}\text { Nhiều dự án giao } \\
\text { thông và cải tạo đô } \\
\text { thị được hoàn thành, } \\
\text { gốp phần định hình } \\
\text { cấu trúc không gian } \\
\text { theo các quy hoạch } \\
\text { phát triển đô thị }\end{array}$ \\
\hline
\end{tabular}

Hình 1. Các giai đoạn phát triển đô thị thành phố Hồ Chí Minh 
Nguồn: Sở xây dựng Thành phố Hồ Chí Minh, Đại học Việt Đức (2018)

\subsubsection{Thực trạng nguồn cung thị trường nhà ở}

Thị trường bất động sản thành phố, sau giai đoạn bị khủng hoảng đóng băng, đã phục hồi và đi vào chu kỳ tăng trưởng trở lại kể từ cuối năm 2013 cho đến nay. Thị trường bất động sản có mối quan hệ mật thiết với tình hình phát triển kinh tế - xã hội, và tình hình tăng trưởng GDP của cả nước và tăng trưởng GRDP của thành phố. Năm 2015, thị trường bất động sản đã đạt mức tăng trưởng cao; năm 2016 có sự sụt giảm nhẹ; năm 2017 thị trường bất động sản tăng trưởng trở lại, mức tăng khoảng 4,07\% so với năm 2016, đóng góp $0,21 \%$ trong tổng mức tăng trưởng GDP của cả nước theo số liệu của Tổng cục thống kê và tiếp tục xu thế tái cấu trúc thị trường, tái cơ cấu đầu tư để có sự tập trung phát triển mạnh hơn phân khúc nhà ở vừa túi tiền đáp ứng nhu cầu thực của người tiêu dùng. Phân khúc nhà ở trung cấp và nhà ở bình dân chiếm tỷ trọng khoảng 60-70\% thị trường, là phân khúc chủ đạo của thị trường bất động sản thành phố, có tính thanh khoản cao nhất, góp phần đảm bảo an sinh xã hội về nhà ở cho người có thu nhập trung bình, thu nhập thấp, công nhân lao động, sinh viên và người nhập cư.

\section{Bảng 2}

Thị trường bất động sản thành phố Hồ Chí Minh 5 tháng đầu năm 2018 so với cùng kỳ 2017

\begin{tabular}{|l|c|c|c|}
\hline & $\mathbf{5}$ tháng đầu năm $\mathbf{2 0 1 7}$ & $\mathbf{5}$ tháng đầu năm $\mathbf{2 0 1 8}$ & Tỷ lệ \\
\hline $\begin{array}{l}\text { Tổng số dự án đủ điều kiện } \\
\text { huy động vốn đưa ra thị trường }\end{array}$ & 32 dự án & 29 dự án & Giảm 9,4\% \\
\hline $\begin{array}{l}\text { Tổng số căn nhà đưa ra thị } \\
\text { trường }\end{array}$ & 16.506 căn & $\begin{array}{c}9.174 \text { căn (gồm có } \\
8.690 \text { căn hộ chung cư } \\
\text { và } 484 \text { căn nhà thấp } \\
\text { tầng) }\end{array}$ & Giảm 44,5\% \\
\hline Căn hộ cao cấp & 5.164 căn & 3.828 căn & Giảm $25,9 \%$ \\
\hline Căn hộ trung cấp & 5.136 căn & 3.465 căn & Giảm 32,6\% \\
\hline căn hộ bình dân & 6.206 căn & 1.881 căn & Giảm $69,7 \%$ \\
\hline
\end{tabular}

Nguồn: Hiệp hội bất động sản Tp.HCM

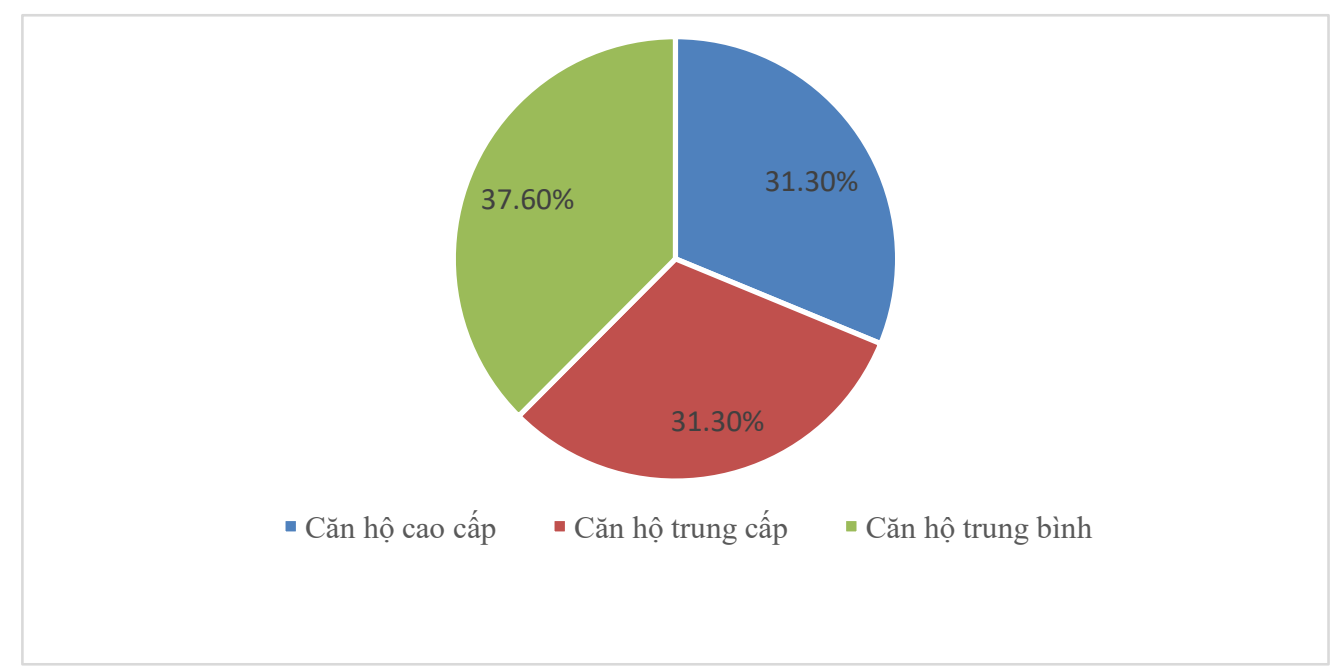

Hình 2. Tỷ lệ các loại căn hộ trong năm 2017

Nguồn: Tác giả tổng hợp theo báo cáo của Hiệp hội bất động sản Tp.HCM 


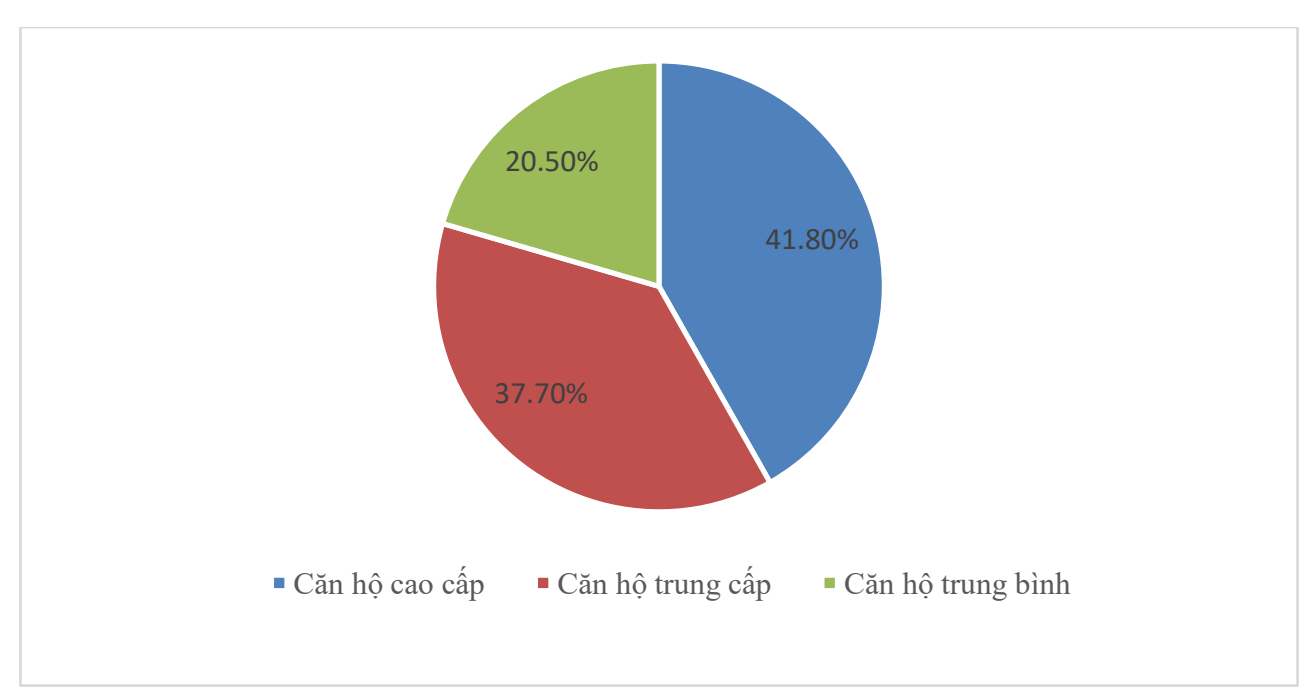

Hình 3. Tỷ lệ các loại căn hộ trong năm 2018

Nguồn: Tác giả tổng hợp theo báo cáo của Hiệp hội bất động sản Tp.HCM

Tuy nhiên, tỷ lệ căn hộ cao cấp lại chiếm đến 41,8\% thị trường, tăng nhiều so với cùng kỳ năm 2017 (chiếm 31,3\%); Phân khúc căn hộ trung cấp có 3.465 căn, giảm 32,6\% so với 5.136 căn cùng kỳ năm 2017. Tỷ lệ căn hộ trung cấp chiếm 37,7\% thị trường, cao hơn so với cùng kỳ năm 2017 (chiếm 31,1\%); Phân khúc căn hộ bình dân có 1.881 căn, giảm mạnh đến $69,7 \%$ so với 6.206 căn cùng kỳ năm 2017. Tỷ lệ căn hộ bình dân chỉ chiếm 20,5\%, giảm gần một nửa so với cùng kỳ năm 2017 (chiếm 37,6\%).

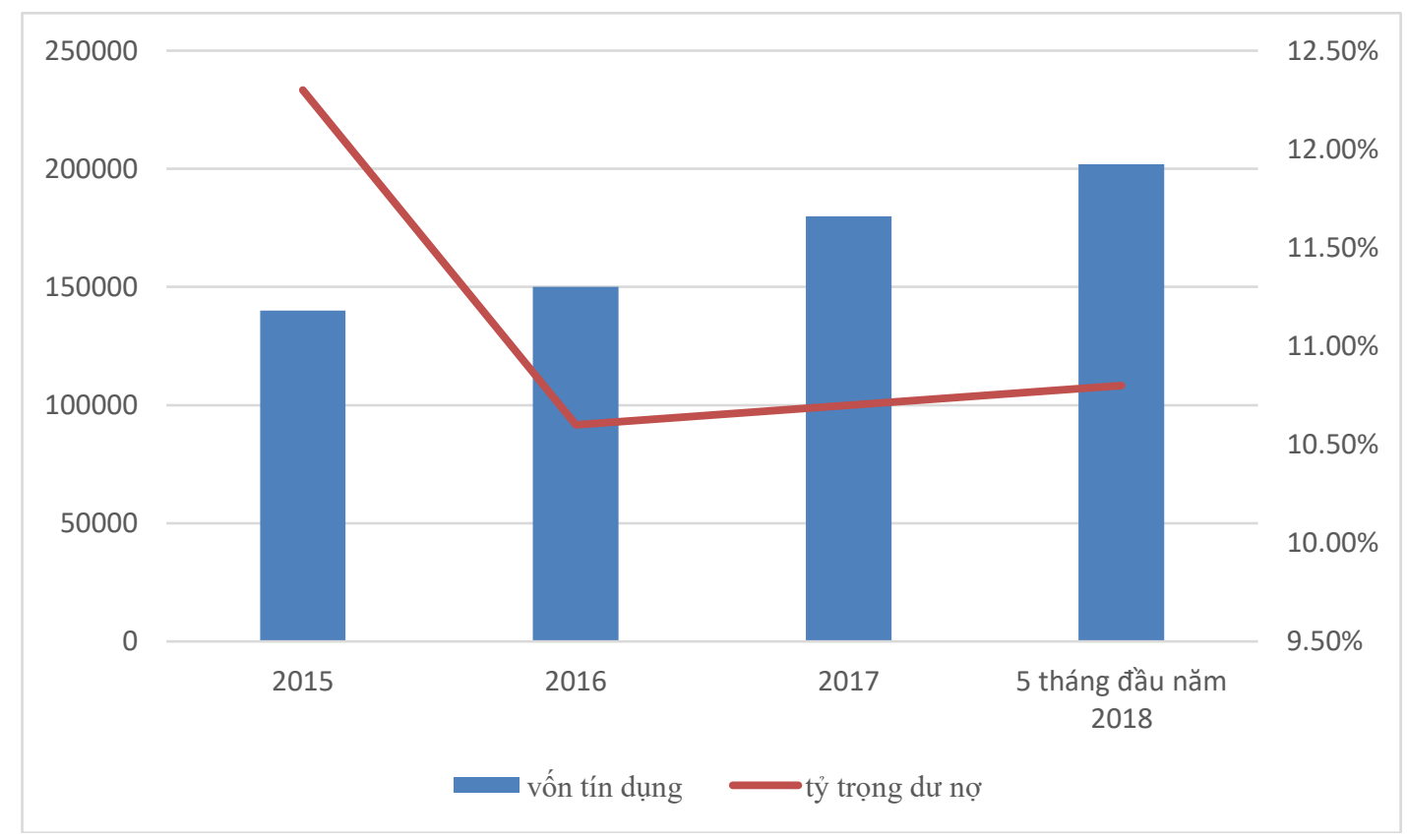

Hình 4. Vốn tín dụng và tỷ trọng dư nợ trên thị trường bất động sản từ năm 2015 đến 5 tháng đầu năm 2018

Nguồn: tác giả tổng hợp theo báo cáo của Hiệp hội bất động sản TpHCM 


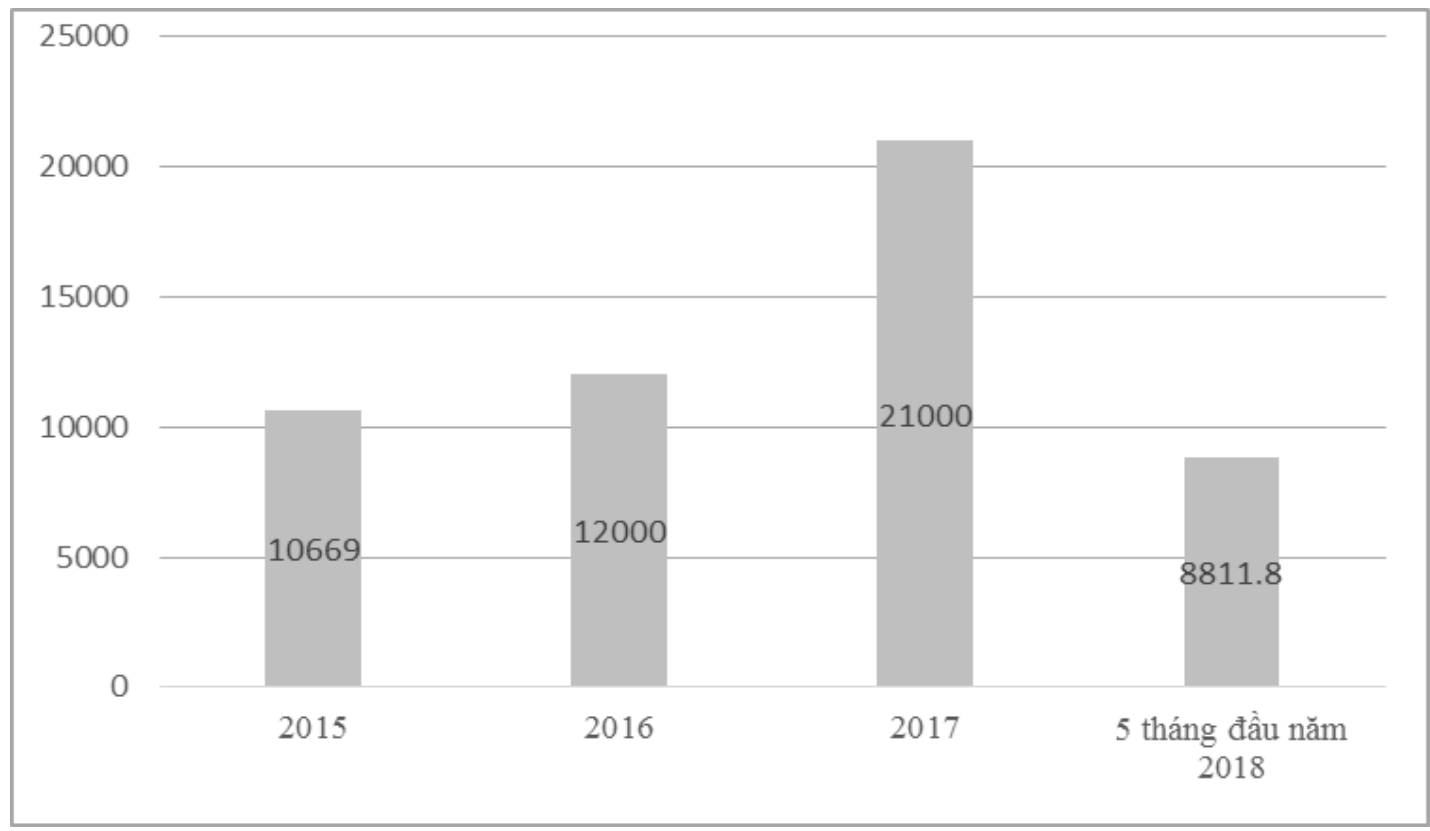

Hình 5. Tiền thu thuế sử dụng đất qua các năm từ năm 2015 đến 5 tháng đầu năm 2018

Nguồn: Tác giả tổng hợp theo báo cáo của Hiệp hội bất động sản Tp.HCM

Nguồn thu ngân sách thành phố từ đất tăng hàng năm, chiếm tỷ trọng khoảng $10 \%$ tổng nguồn thu, như: Năm 2015, thu tiền sử dụng đất đạt 10.669 tỷ đồng; Năm 2016, thu tiền sử dụng đất khoảng 12.000 tỷ đồng; Năm 2017, thu hơn 21.000 tỷ đồng, chiếm tỷ lệ 9,5\%; Hơn 05 tháng đầu năm 2018 , đã thu $8.811,8$ tỷ đồng tiền sử dụng đất, đạt $60,7 \%$ tổng dự toán, tăng $0,75 \%$, đã thu 2.013,4 tỷ đồng tiền thuê đất, đạt $36,6 \%$ dự toán, giảm $16,9 \%$ so với cùng kỳ (Kết quả thực hiện hiệu quả hơn trước do thực hiện cơ chế mới, Phó Chủ tịch Ủy ban nhân dân thành phố là Chủ tịch Hội đồng thẩm định giá đất). Nguồn vốn tín dụng vào thị trường bất động sản thành phố đã tăng từ năm 2015 đến nay, như: Năm 2015, đạt khoảng 140.000 tỷ đồng, chiếm 12,3\% tổng dư nợ; Năm 2016, đạt khoảng 150.000 tỷ đồng, chiếm 10,6\% tổng dư nợ; Năm 2017, đạt khoảng 180.000 tỷ đồng, chiếm 10,7\% tổng dư nợ; Hơn 05 tháng đầu năm 2018, đạt khoảng 202.000 tỷ đồng, chiếm 10,8\% tổng dư nợ (cao hơn mức bình quân cả nước).

Nguồn vốn đầu tư nước ngoài $(F D I)$, một trong những thước đo kết quả hội nhập của nền kinh tế, của thị trường bất động sản nước ta, có xu thế tăng dần trong những năm gần đây, trong đó, thị trường bất động sản thường giữ vị trí thứ 3 trong việc thu hút vốn FDI, đồng thời, bổ sung thêm nguồn vốn quan trọng cho doanh nghiệp trong xu thế các ngân hàng thương mại đang dần hạn chế cấp tín dụng bất động sản. 


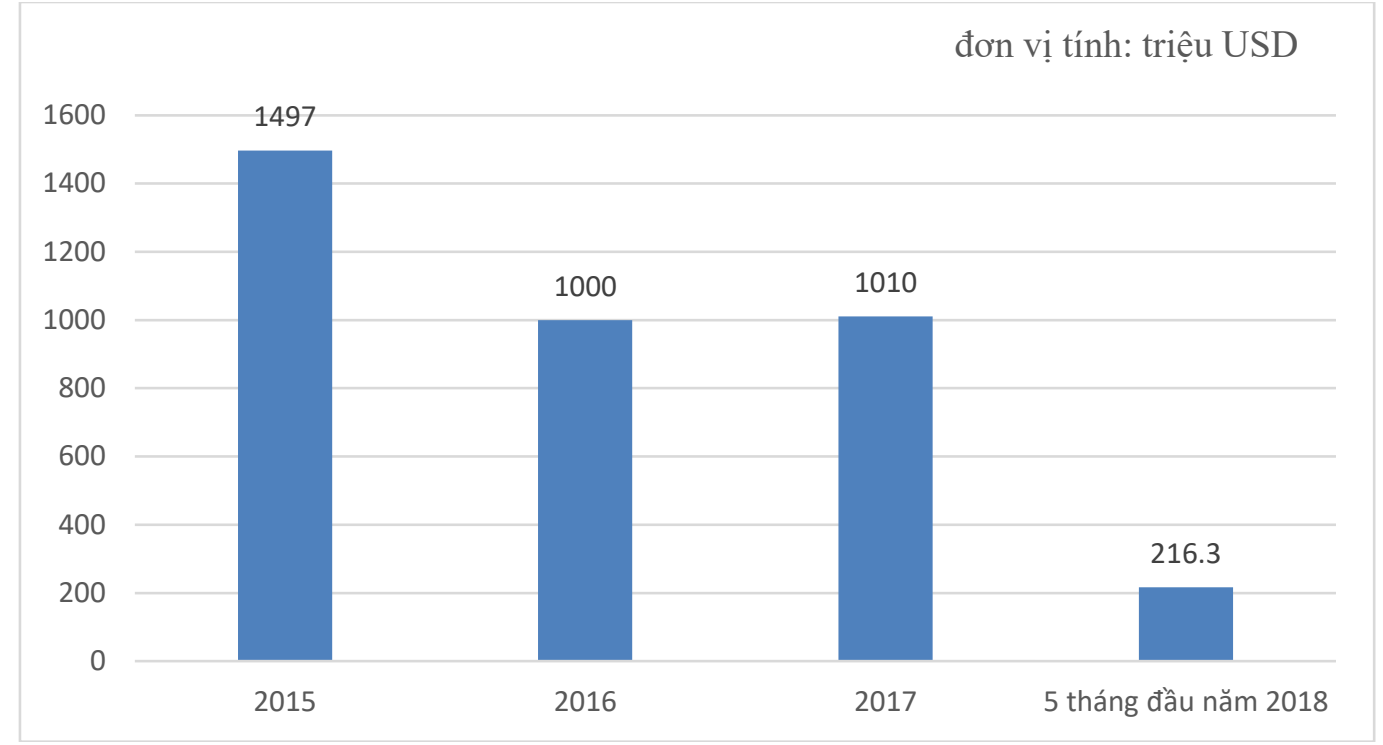

Hình 6. Vốn FDI vào thị trường bất động sản TPHCM từ 2015 đến 5 tháng đầu năm 2018

Nguồn: Tác giả tổng hợp theo báo cáo của Hiệp hội bất động sản Tp.HCM

Riêng thành phố Hồ Chí Minh, có năm thị trường bất động sản giữ vị trí thứ nhất trong các năm 2015, năm 2017, và 05 tháng đầu năm 2018, như: Năm 2015, đạt 1,497 tỷ USD (chiếm 53,3\%); Năm 2016, có sự sụt giảm, chỉ đạt 1 tỷ USD; Năm 2017, tăng mạnh, đạt 1,01 tỷ USD; Trong 05 tháng đầu năm 2018, đạt 216,3 triệu USD. Tính đến hết năm 2017, toàn thành phố có 7.372 dự án FDI còn hiệu lực với tổng vốn đầu tư gần 45 tỷ USD, chiếm 32,4\% tổng nguồn vốn FDI. Các nguồn vốn FDI vào thị trường bất động sản là từ Nhật Bản, Hàn quốc, Singapore, Hongkong, Đài Loan, Hoa Kỳ, và gần đây là Trung quốc. Điển hình tại thành phố Hồ Chí Minh là Công ty Liên doanh Phú Mỹ Hưng; Công ty Nam Long hợp tác với Hankyu Hanshin Toho Group, và Nishi Nippon Railroad (Japan); Công ty Tiến Phước, Trần Thái hợp tác với Keppel Land (Singapore); Công ty Tiến Phát hợp tác với Sanyo Home (Japan); Công ty An Gia hợp tác với Creed Group (Japan); Công ty Phúc Khang hợp tác với Mitsubishi Corporation (Japan), và Qủy Genesis Global Capital (Singapore); CII hợp tác với Hongkong Land; Sơn Kim Land hợp tác với Hankyu Hanshin; Capitaland, VinaCapital, Lotte, Dragon Capital... cũng là những nhà đầu tư bất động sản lớn tại Việt Nam. Nguồn kiều hối gửi về nước hàng năm giữ ở mức trên dưới 10 tỷ USD, trong đó, thành phố Hồ Chí Minh chiếm khoảng $50 \%$, và có khoảng $21 \%$ đầu tư vào bất động sản. Trong năm 2017, đã có 11 doanh nghiệp bất động sản lên sàn chứng khoán. Trong hơn 5 tháng đầu năm 2018, đã có 04 doanh nghiệp lên sàn là Vinhomes thuộc Tập đoàn Vingroup, Net Land, Văn Phú Invest, Đạt Phương. Dự kiến từ nay đến cuối năm sẽ có thêm nhiều doanh nghiệp bất động sản lên sàn chứng khoán như Hưng Thịnh Construction, Cenland, MBland, Hải Phát... Đây là hướng đi phù hợp và hiệu quả nhằm khẳng định uy tín thương hiệu, tính minh bạch và giải trình, tạo điều kiện huy động các nguồn vốn trong và ngoài nước, giảm dần sự phụ thuộc vào nguồn vốn tín dụng ngân hàng; Thành phố đã có gần 16.500 doanh nghiệp đăng ký thành lập mới, với tổng vốn đăng ký gần 186.000 tỷ đồng, tăng 6,5\% về số lượng doanh nghiệp và giảm hơn $4 \%$ về vốn so với cùng kỳ năm 2017 . Trong đó, có 3.385 doanh nghiệp có đăng ký kinh doanh bất động sản, chiếm 20,5\%.

\subsubsection{Tình hình phía cung nhà ở cho nguời thu nhập trung bình}

Trước năm 1975, trên địa bàn thành phố đã có 474 chung cư thấp tầng (phần lớn là 04 tầng) với những căn hộ nhỏ có diện tích chỉ khoảng $28-30 \mathrm{~m}^{2}$, trong đó có nhiều căn hộ được 
người dân cơi nới thêm gác lửng bằng vật liệu nhẹ, không đồng nhất và không đảm bảo mỹ quan, điển hình như chung cư Nguyễn Thiện Thuật, quận 3, chung cư Ngô Gia Tự, chung cư Nguyễn Kim, quận 10, chung cư Thanh Đa, quận Bình Thạnh... và các hộ gia đình đã sử dụng trong 50 năm qua;

Từ năm 1975 đến nay, thành phố đã bố trí chỗ ở cho cán bộ, công nhân viên, người lao động tại nhiều chung cư và nhà tập thể cũ, trong đó, có những chung cư, nhà tập thể với các căn phòng ở rất nhỏ, chỉ có diện tích khoảng $10-20 \mathrm{~m}^{2}$, như chung cư 727 Trần Hưng Đạo, quận 5 , có 12 tầng với hơn 500 căn hộ... Đồng thời, thành phố cũng đã phát triển nhiều khu nhà chung cư, nhà lưu trú công nhân, ký túc xá sinh viên để giải quyết một phần nhu cầu nhà ở của cán bộ, công chức, viên chức nhà nước, cán bộ lực lượng vũ trang, người thu nhập thấp đô thị, công nhân lao động và người nhập cư, tiêu biểu như: 1.000 căn hộ bán trả góp đầu tiên của cả nước tại khu dân cư Bàu Cát, quận Tân Bình; Thực hiện chỉnh trang đô thị, xây dựng chung cư Xóm Cải, quận 5; Xây dựng mới các chung cư Nguyễn Kiệm, quận Phú Nhuận, Phan Văn Trị, Đinh Bộ Lĩnh quận Bình Thạnh; các chung cư đường Hoàng Diệu, quận 4.., nhưng số lượng vẫn còn ít, chưa đáp ứng kịp nhu cầu nhà ở giá rẻ rất lớn của nhân dân thành phố;

Sau năm 2000, các doanh nghiệp đã đầu tư phát triển các dự án nhà ở thương mại vừa túi tiền, và đến nay đã có những doanh nghiệp tiên phong đầu tư nhà ở xã hội, trong đó, có nhiều doanh nghiệp đã đầu tư bằng nguồn vốn ngoài ngân sách, tại các quận ven và huyện ngoại thành, tiêu biểu như:

Công ty Lê Thành chuyên đầu tư căn hộ nhà ở thương mại vừa túi tiền để cho thuê, hoặc bán cho công nhân, lao động, người thu nhập thấp đô thị với hơn 4.500 căn hộ, và cũng là doanh nghiệp tư nhân đầu tiên đã đầu tư các dự án nhà ở thương mại có diện tích $29 \mathrm{~m}^{2} /$ căn cho thuê dài hạn 49 năm. Ông Lê Hữu Nghĩa - Giám đốc Công ty, với tư cách cá nhân đã đầu tư đưa ra thị trường 02 chung cư thấp tầng với quy mô 285 căn hộ nhỏ $19 \mathrm{~m}^{2} /$ căn, cho thuê với giá chỉ 1,5 triệu đồng/ tháng, đặt cọc 01 tháng tiền thuê nhà. Công ty đang thực hiện dự án chung cư nhà ở xã hội gồm 930 căn hộ nhà ở xã hội cho thuê dài hạn, có diện tích $38 \mathrm{~m}^{2} /$ căn hộ (có thể chia ra làm 02 phòng cho thuê với diện tích $19 \mathrm{~m}^{2} /$ phòng) tại phường An Lạc, quận Bình Tân; Công ty Thiên Phát đã đầu tư dự án chung cư nhà ở xã hội (giai đoạn 1) gồm 2.500 chỗ ở cho công nhân thuê tại khu công nghiệp Linh Trung 2 và đang thực hiện giai đoạn 2. Công ty cũng đang đề nghị được đầu tư các dự án nhà ở xã hội tại Khu công nghệ cao thành phố Hồ Chí Minh; Tổng Công ty Địa ốc Sài Gòn (Resco) đã đầu tư khu nhà lưu trú công nhân đầu tiên của thành phố tại Khu chế xuất Linh Trung, quận Thủ Đức; Tanimex đã đầu tư khu nhà lưu trú công nhân tại Khu công nghiệp Tân Bình; Công ty Hoàng Quân đã hoàn thành đưa vào sử dụng khu nhà ở xã hội gồm 1.700 căn tại xã An Phú Tây, huyện Bình Chánh, và đang tiếp tục đầu tư vào 04 dự án nhà ở xã hội tại thành phố, trong đó, có dự án nhà ở xã hội số 35 Hồ Học Lãm, quận Bình Tân hợp tác với Qũy Phát triển nhà ở thành phố gồm 718 căn hộ; Công ty Thủ Thiêm đã hoàn thành đưa vào sử dụng chung cư nhà ở xã hội gồm 304 căn tại phường Thảo Điền, quận 2; Công ty Phú Cường đã đầu tư chung cư nhà ở xã hội tại phường Bình An, quận 2 với 1.087 căn hộ phục vụ cho cán bộ, công nhân viên ngành công an; Công ty Vạn Thái đã đầu tư chung cư Topaz Home 1 nhà ở xã hội tại phường Tân Thới Nhất, quận 12 với 1.100 căn hộ, Topaz Home 2 tại phường Tân Phú, quận 9 với 1.100 căn hộ; Công ty Phát triển Công nghiệp Tân Thuận (ITC) đã dành quỹ đất đầu tư các dự án nhà ở công nhân tại khu chế xuất Tân Thuận; Ban Quản lý Khu Công nghệ cao thành phố đã quy hoạch 20,1 ha để thực hiện các dự án khu nhà ở cho chuyên gia và công nhân, lao động; Công ty Nam Long đã thực hiện 08 dự án nhà ở thương mại vừa túi tiền EHome và đang triển khai đầu tư các dự án nhà ở xã hội EHomeS tại quận 9 và huyện Bình Chánh. Trong điều kiện chưa có nguồn vốn tín dụng ưu đãi, Công ty Nam Long đã hỗ trợ $2 \% /$ năm lãi suất vay cho người mua dự án nhà ở xã hội EHomeS Phú Hữu, quận 9, người mua vẫn còn phải trả lãi 
vay 7\%/năm cho ngân hàng. Trong lĩnh vực nhà ở tái định cư, nhà ở thương mại giá thấp, còn có nhiều doanh nghiệp tham gia, như Công ty Đức Khải đã thực hiện 03 dự án nhà ở tái định cư tại phường Phú Mỹ, quận 7, phường Bình An, quận 2 và tại quận Tân Bình; Công ty Nam Rạch Chiếc đã thực hiện dự án nhà tái định cư tại phường An Phú-Bình Khánh, quận 2; Công ty C.T có các dự án IHome, Bee Home; Công ty Phát triển nhà Thủ Đức có các dự án TDH Apartments; Công ty Hưng Thịnh có các dự án nhà ở vừa túi tiền 12View, $8 \mathrm{X}$, Melody, Florita, Mia; Công ty Phúc Khang có các dự án Eco City, Làng Sen, Diamond Lotus; các công ty Him Lam, Nhà Mơ, Thuận Việt, Phương Việt, Thuận Kiều, Vạn Thái, Kiến Á, Địa Ốc Việt, Rio Land, An Gia, Hoàng Anh Gia Lai, Vietcomreal, Hưng Ngân, Tecco, Đất Lành... đã đầu tư phát triển nhiều dự án nhà ở vừa túi tiền, dự án căn hộ nhỏ đáp ứng nhu cầu của người có thu nhập trung bình, người có thu nhập thấp đô thị, người nhập cư.

\subsubsection{Thực trạng nhu cầu về nhà ở đô thị tại thành phố Hồ Chí Minh}

Hiện nay, quy mô dân số thành phố Hồ Chí Minh đã lên đến gần 13 triệu người, trong đó có gần 3 triệu người nhập cư, chiếm khoảng 23\% dân số; có hơn 400.000 sinh viên; hàng năm có thêm hơn 50.000 cặp kết hôn mới; Qua khảo sát của Sở Xây dựng, Viện nghiên cứu phát triển thì có khoảng 500.000 hộ chưa có nhà; có khoảng 81.000 hộ cần nhà ở xã hội. Trong đội ngũ cán bộ, công chức, viên chức nhà nước tại thành phố, thì đã có khoảng 139.000 người chưa có nhà ở, cần khoảng 80.000 căn hộ; Trong tổng số hơn 402.000 công nhân, lao động đang làm việc tại 17 khu chế xuất, khu công nghiệp, khu công nghệ cao của thành phố thì có đến 284.000 người (chiếm 70,6\%) có nhu cầu nơi lưu trú, nhưng hiện chỉ mới giải quyết được chỗ ở cho 39.400 người, chiếm khoảng $15 \%$ nhu cầu. Chỉ riêng khu nhà máy may mặc của Công ty Pou Yuen, quận Bình Tân đã có khoảng 100.000 công nhân lao động, trong đó, hơn $80 \%$ là công nhân đến từ các tỉnh, nhất là Long An. Hầu hết công nhân, lao động này đều đang phải thuê phòng trọ, nhà trọ. Do vậy, giải quyết nhu cầu nhà ở xã hội, nhà ở thương mại giá thấp, trước hết là phải có nhiều căn hộ cho thuê giá thấp, có đủ các tiện ích cơ bản và an toàn hơn cần phải được coi là nhiệm vụ chính trị của thành phố, có tính nhân văn và có ý nghĩa xã hội rất sâu sắc, đảm bảo an sinh xã hội, an ninh chính trị. Trong lúc hiện nay, đang rất thiếu nhà ở xã hội cho thuê, và căn hộ nhà ở thương mại cho thuê giá thấp (giá thuê tù 1 - 3 triệu đồng/tháng). Các ký túc xá thuộc Đại học Quốc gia thành phố Hồ Chí Minh và các trường đại học khác đã giải quyết được chỗ ở cho khoảng 25.000 sinh viên và còn có khả năng tiếp nhận thêm khoảng 25.000 sinh viên nữa. Nhìn chung, các ký túc xá sinh viên, các khu lưu trú công nhân trên địa bàn thành phố hiện nay mới chỉ giải quyết nhu cầu chỗ ở được khoảng $15 \%$, và có đến khoảng $70 \%$ nhu cầu chố ở của sinh viên, công nhân, lao động, người nhập cư là do các hộ gia đình, cá nhân đầu tư các khu nhà trọ, phòng trọ tạm bợ, phần lớn không đủ tiện ích, không đảm bảo an toàn, an ninh; Dự báo nhu cầu nhà ở vừa túi tiền, nhà ở thương mại giá rẻ, nhà ở xã hội, nhà ở cho thuê giá rẻ trên địa bàn thành phố trong 10 năm tới có thể lên đến khoảng 1 triệu căn.

\subsection{4. Đánh giá thị truòng nhà ở đô thị cho người thu nhập trung bình tại thành phố Hồ}

\section{Chí Minh}

Nhà ở đô thị nói chung và nhà ở đô thị cho người thu nhập trung bình nói riêng tại thành phố Hồ Chí Minh kết quả còn rất khiêm tốn. Những chương trình thực hiện về phát triển nhà ở xã hội theo báo cáo của Sở xây dựng cho thấy thành quả nổi bật liên quan đến công tác chỉnh trang đô thị, nâng cao mức sống dân cư ven kênh rạch vốn có điều kiện sống thấp với khoảng 30.000 hộ gia đình được cải thiện điều kiện sống hoặc thay đổi chỗ ở mới. Ngoài ra, các chương trình nhà ở trọng điểm về phát triển nhà ở xã hội như: chương trình nhà lưu trú công nhân, ký túc xá sinh viên, chương trình nhà ở cho cán bộ, công nhân viên chức, sĩ quan chuyên nghiệp, nhà ở cho người thu nhập trung bình và thu nhập thấp đều không đạt mục tiêu đề ra. 
Những nguyên nhân dẫn đến việc mất cân đối giữa cung và cầu trên thị trường bất động sản đô thị dành cho đối tượng thu nhập trung bình có thể kể đến như sau: (1) Nguyên nhân đầu tiên là quy trình thiết lập dự án và xây dựng nhà ở phức tạp tốn nhiều thời gian của chủ đầu tư khiến cho các chủ đầu tư không muốn tham gia vào thị trường kém hấp dẫn về thương mại này. Chủ đầu tư nhà ở xã hội chỉ được phép hưởng $10 \%$ lợi nhuận biên. Khi tiến hành xây dựng, chủ đầu tư cũng không được quyết định giá bán, giá thuê mà phải theo mức trần do địa phương quy định, do đó họ không chủ động trong chiến lược kinh doanh của mình. (2) Sự thiếu hụt vốn đầu tư dành cho nhà ở xã hội cũng là nguyên nhân dẫn đến tình trạng hạn chế. Hiện tại, đa số các dự án nhà ở xã hội đều xây dựng bằng vốn đầu tư công, nhưng nguồn vốn ngân sách trung ương và địa phương dành cho lĩnh vực này bị giới hạn. Luật nhà ở 2005 có quy định $30-50 \%$ phí sử dụng đất địa phương từ các dự án nhà ở thương mại phải dùng để phát triển nhà ở xã hội. Tuy nhiên, địa phương lại ưu tiên ngân sách cho những việc cấp bách hơn. Ngoài ra, nghị định 188 năm 213 quy định các doanh nghiệp phát triển nhà ở xã hội không thể sử dụng đất để thế chấp cho các khoản vay vốn phục vụ cho dự án, dẫn đến khó khan trong việc huy động vốn. (3) Một nguyên nhân khác là thiếu quỹ đất dành cho nhà ở xã hội. Việc thiếu đất có thể từ công tác quy hoạch chưa chủ động phân rõ khu đất dành riêng cho việc xây nhà ở xã hội. Theo quy định, $20 \%$ diện tích đất trong các dự án nhà ở cần phải dành cho nhà ở xã hội nhưng thực tế quy định này chưa phát huy hiệu quả. (4) Một sự khác biệt trong khái niệm nhà ở xã hội giữa các nước. Ở một số nước (như nước Pháp và Đức) xác định đối tượng ưu tiên cho nhà ở xã hội dựa vào yếu tố kinh tế (cụ thể là thu nhập), sau đó người dân được quyền chọn nhà phù hợp theo nhu cầu và khả năng của họ, không có ràng buộc về khu ở hoặc nơi chốn. Còn Việt Nam, khi lựa chọn đối tượng thụ hưởng thì có nhiều yếu tố về diện tích ở hiện tại, tình trạng cư trú...cunng đóng vai trò quan trọng. Người dân chỉ có một số lựa chọn hạn chế về nơi ở phù hợp từ một số dự án, nơi chốn được định trước. Thực tế này dẫn tới việc khi người dân đã thụ hưởng từ các chương trình nhà ở xã hội, họ bắt buộc phải chịu các ràng buộc liên quan đến nơi chốn và không gian sinh sống, ngay cả khi lựa chọn đó không hề phù hợp với cuộc sống hằng ngày của họ.

\section{3. Đề xuất một số giải pháp cho thị trường nhà ở đối tượng thu nhập trung bình}

\subsection{Nhóm giải pháp phát triển cung}

\subsubsection{Nên phát triển căn hộ cho thuê giá rẻ hơn là phát triển căn hộ nhà ở xã hội $30 m 2$}

Một cách để cải thiện khả năng chi trả về nhà ở cho người thu nhập trung bình là giảm giá nhà. Qua bài học của Bình Dương, Sở xây dựng Thành phố Hồ Chí Minh cho rằng thành phố vẫn có thể làm được căn hộ nhà ở xã hội $30 \mathrm{~m}^{2}$ (gồm $20 \mathrm{~m}^{2}$ sàn và $10 \mathrm{~m}^{2}$ gác lửng), có giá bán khoảng trên dưới 200 triệu đồng/căn tại một số khu vực có điều kiện tương đồng như tỉnh Bình Dương. Điều kiện thực hiện là đã có sẵn hệ thống hạ tầng giao thông; bên cạnh các khu công nghiệp, nơi làm việc; đã có các tiện ích, dịch vụ cơ bản như trường học, nhà trẻ, mẫu giáo, bệnh viện, khu vui chơi giải trí, thể dục thể thao, công viên; có nền địa chất vững chắc.

Các khu vực có thể phát triển loại hình nhà ở $30 \mathrm{~m}^{2}$ với giá 200 triệu là Khu chế xuất Linh Trung I, II, III (326 ha), Khu công nghệ cao (913 ha), Công viên phần mềm Quang Trung (43 ha), Đại học quốc gia thành phố Hồ Chí Minh (647 ha; trong đó có khoảng 2/3 diện tích thuộc Bình Dương). Riêng Khu đô thị công nghiệp cảng biển Hiệp Phước (3.600 ha) có điều kiện thuận lợi về quỹ đất nhưng do nền đất yếu, lại chưa phát triển đầy đủ hệ thống hạ tầng, dịch vụ nên chi phí đầu tư loại nhà này sẽ cao hơn; Khu chế xuất Tân Thuận (320 ha).

Với quỹ đất công nêu trên, thành phố Hồ Chí Minh có thể làm được khoảng 10.000 căn hộ nhà ở xã hội $30 \mathrm{~m}^{2}$ có giá bán khoảng trên dưới 200 triệu đồng/căn, nhưng sẽ chỉ có khoảng 10.000 người mua được loại nhà này chiếm khoảng $1 \%$ người có nhu cầu. Như vậy, đa số công 
nhân, lao động, người thu nhập thấp và người nhập cư sẽ không còn loại nhà này để mua, nên chưa đảm bảo công bằng xã hội và cũng chưa giải quyết được nhu cầu rất lớn của xã hội; Trong lúc các khu công nghiệp, khu công nghệ cao lại cần phát triển nhiều căn hộ nhà ở xã hội cho thuê có diện tích từ $25-50 \mathrm{~m}^{2} /$ căn, thì phù hợp với nhu cầu thực tế và của các lớp công nhân, lao động. Với đặc thù của thành phố, tập trung phát triển chủ yếu là loại căn hộ nhà ở xã hội 1-2 phòng ngủ, diện tích khoảng $25-77 \mathrm{~m}^{2}$, có giá bán khoảng 250-800 triệu đồng/căn. Như vậy xu hướng đề xuất là xây nhà ở cho thuê phù hợp nhu cầu hiện nay.

\subsubsection{Giải pháp về xác định quy hoạch, thiết kế, quy định trong quản lý}

Theo kinh nghiệm các nước về phát triển nhà ở đô thị cho nhóm đối tượng thu nhập trung bình, cần có những khu vực quy hoạch riêng cho nhà ở loại này. Hiện nay, nhà ở xã hội nằm trong nhà ở thương mại. Điều này gây nên những hệ quả không tốt cho cả cư dân thuộc nhà ở thương mại và nhà ở xã hội. Phía đối tượng nhà ở thương mại, sẽ cảm thấy khu vực sinh sống của mình giá trị bị hạ thấp, xảy ra tình trạng so sánh giá vì cùng khu vực lại tồn tại 2 mức giá bán căn hộ khác nhau. Phía đối tượng thụ hưởng nhà ở xã hội, họ chịu các khoảng chi phí cao khi sinh sống trong khu vực thương mại.

Cần có những quy định về thiết kế nhà ở xã hội nói chung và nhà ở cho nhóm đối tượng thu nhập trung bình nói riêng, cách xác định chất lượng nhà ở, gắn liền với các quy định về quản lý toàn nhà thuộc dạng này.

\subsection{Nhóm giải pháp hỗ trọ cầu}

\subsubsection{Giải pháp về múc gửi tiết kiệm nhà ở xã hội}

Tại văn bản số 2510/NHCS-TDSV ngày 26/07/2016, Ngân hàng Chính sách xã hội quy định khách hàng là hộ gia đình, cá nhân khi vay vốn ưu đãi phải thực hiện gửi tiết kiệm với "Mức gửi hàng tháng tối thiểu bằng mức trả nợ hàng tháng của người vay vốn". Quy định này sẽ dẫn đến mức gửi tiết kiệm khác nhau do giá mua nhà ở xã hội khác nhau (do có căn hộ 1 phòng ngủ, 2 phòng ngủ trong cùng tòa nhà chung cư, hoặc giữa các dự án NOXXH khác nhau). Hơn nữa, trường hợp người gửi tiết kiệm chưa đến lượt được mua nhà ở xã hội (do nguồn cung không đáp ứng kịp nhu cầu) thì sẽ không xác định được "mức trả nợ hàng tháng" để gửi tiền tiết kiệm. Ngoài ra, quy định này còn có điểm bất hợp lý là mức gửi tiết kiệm hàng tháng cao, bên cạnh đó người mua nhà ở xã hội còn phải trả lãi vay hàng tháng trong năm đầu do chưa phải trả nợ gốc, và trước đó đã phải trả $20 \%$ giá trị hợp đồng mua nhà ở xã hội, thì toàn bộ chi phí hàng tháng sẽ là gánh nặng cho người mua nhà ở xã hội. Do vậy, cần quy định một mức gửi tiền tiết kiệm nhà ở xã hội hàng tháng mà mọi đối tượng thụ hưởng nhà ở xã hội đều thực hiện như nhau, có thể ở mức 500.000 đồng hoặc không quá 1 triệu đồng/tháng thì thuận tiện và phù hợp hơn với khả năng tài chính của người mua nhà ở xã hội.

\subsubsection{Giải pháp về lãi suất tiền gửi tiết kiệm, thời hạn vay, tiền đặt cọc}

Ngân hàng Chính sách xã hội đề nghị mức lãi suất tại Văn bản số 2510/NHCS-TDSV ngày $26 / 07 / 2016$ “đã báo cáo và trình cấp có thẩm quyền quyết định lãi suất tiền gửi tiết kiệm của hộ gia đình, cá nhân có nhu cầu vay vốn nhà ở xã hội bằng lãi suất cho vay nhà ở xã hội cho từng thời kỳ”. Đề xuất này chưa hợp lý. người gửi tiết kiệm tại Ngân hàng Chính sách xã hội cũng được hưởng lãi suất tiết kiệm bằng mức lãi suất tiết kiệm thông thường tại các ngân hàng thương mại (hiện nay khoảng 7\%/năm) đối với các khoản tiền gửi trên 12 tháng, để khuyến khích đối tượng thụ hưởng nhà ở xã hội tham gia, tạo thêm nguồn lực thực hiện chính sách nhà ở xã hội. Lãi suất cho vay ưu đãi nhà ở xã hội hiện nay là 4,8\%/năm (lãi suất quá hạn 130\% lãi suất vay) khi vay tại Ngân hàng chính sách xã hội; và $5 \% /$ năm (lãi suất quá hạn $150 \%$ lãi suất 
vay) khi vay tại 04 ngân hàng thương mại do Nhà nước chỉ định là chưa hợp lý, mà nên thống nhất cùng một mức lãi suất vay, cùng mức lãi suất quá hạn, và cùng thực hiện tiết kiệm nhà ở xã hội như nhau. Về lâu dài, khi nền kinh tế phát triển mạnh hơn, thực hiện mức lãi suất ưu đãi vay mua nhà ở xã hội từ 3-3,5\%/năm thì phù hợp hơn.

Về thời hạn cho vay mua, thuê mua nhà ở xã hội và định kỳ hạn trả nợ, theo quy định tại khoản 6 điều 16 Nghị định 100/2015/NĐ-CP ngày 20/10/2015 của Chính phủ và tại khoản 4 điều 7 Thông tư 25/2015/TT-NHNN ngày 09/12/2015 của Ngân hàng Nhà nước đối với khách hàng vay tín dụng ưu đãi để mua, thuê mua nhà ở xã hội thì đều đã quy định: "Thời hạn cho vay tối thiểu là 15 năm kể từ ngày giải ngân khoản vay đầu tiên". Ngày 27/07/2016, Ngân hàng Chính sách xã hội đã ban hành hướng dẫn số 2526/NHCS-TDSV, tại mục 6 đã quy định "Thời hạn cho vay tối thiểu là 15 năm và tối đa không quá 25 năm kể từ ngày giải ngân khoản vay đầu tiên"; và tại mục (11.b) đã quy định: "Người vay vốn chưa phải trả nợ gốc trong thời gian ân hạn 12 tháng kể từ ngày nhận khoản vay đầu tiên”. Các quy định này rất tốt, rất có lợi cho đối tượng thụ hưởng nhà ở xã hội, nhưng có thể đã vượt quá thẩm quyền của Ngân hàng Chính sách xã hội, bởi lẽ: (i) Thời hạn cho vay có liên quan đến cơ chế tái cấp vốn, cấp bù lãi suất thuộc thẩm quyền của Chính phủ và Ngân hàng Nhà nước quy định cho Ngân hàng Chính sách xã hội và các tổ chức tín dụng được chỉ định; (ii) Đối tượng nào được vay 15 năm, đối tượng nào được vay 20 năm, đối tượng nào được vay 25 năm... có thể dẫn tới cơ chế "xin - cho", vận dụng tùy tiện; (iii) Việc quy định ân hạn chưa phải trả nợ gốc thuộc thẩm quyền của Ngân hàng Nhà nước. Do vậy, cần quy định thời hạn cho vay mua nhà ở xã hội trong từng thời kỳ; Quy định ân hạn chưa phải trả nợ gốc để thống nhất thực hiện tại Ngân hàng Chính sách xã hội và 04 tổ chức tín dụng do Ngân hàng Nhà nước chỉ định. Thời gian vay cần phải xác định trên 20 năm thì khả năng chi trả của nhóm đối tượng này mới thực hiện được.

\section{Kết luận}

Bài viết đã hệ thống hóa những văn bản pháp luật về nhà ở đô thị, cụ thể là nhà ở xã hội đã phát triển từng bước theo thời gian. Sự thay đổi của hệ thống pháp luật vẫn chưa là công cụ phù hợp để điều tiết thị trường nhà ở. Cung và cầu nhà ở trên thị trường dành cho nhóm đối tượng thu nhập trung bình vẫn còn chưa cân bằng. Số lượng cung vẫn chưa đủ số lượng cầu và nhu cầu vẫn chưa được thực tế cung thỏa đáng. Những nguyên nhân giải thích sự thiếu cân bằng này được tác giả đề cập đến như quy trình phê duyệt dự án phức tạp, thiếu vốn đầu tư, thiếu quỹ đất và đặc biệt là nhu cầu người dân không được tự do lựa chọn dự án theo khả năng chi trả. Tác giả đã đề xuất một số kiến nghị có liên quan việc hỗ trợ phía cung và hỗ trợ phía cầu. Nhóm giải pháp hỗ trợ cung: nên phát triển loại hình căn hộ cho thuê với giá rẻ, xác định quy hoạch, thiết kế, quy định trong quản lý. Nhóm giải pháp hỗ trợ cầu: mức tiền gửi tiết kiệm như nhau cho mọi đối tượng, lãi suất ưu đãi vay mua nhà ở xã hội từ 3-3,5\%/năm, quy định thời hạn cho vay mua nhà ở xã hội trong từng thời kỳ, xác định trên 20 năm, xác định quy hoạch, thiết kế, quy định trong quản lý.

\section{Tài liệu tham khảo}

Bộ xây dựng. (2010). Thông tur số 16/2010/TT-BXD ngày 01/09/2010 về quy định cu thể và hướng dẫn thưc hiện một số nội dung của nghị dịnh số 71/2010/NĐ-CP ngày 23 tháng 6 năm 2010 của Chính phủ quy định chi tiết và huớng dẫn thi hành luật nhà ở [Circular No. 16/2010/TTBXD dated 1 September 2010 on specific regulations and guidance for the implementation of a number of contents of the Government's Decree No. 71/2010/ND-CP 23 dated June 2010 detailing and guiding the implementation of the housing law]. Retrieved May 20, 2019, from https://thuvienphapluat.vn/van-ban/Bat-dong-san/Thong-tu-16-2010-TT-BXD-huong-dan- 
Nghi-dinh-71-2010-ND-CP-ve-Luat-nha-o-111277.aspx

Bộ xây dựng. (2013). Thông tu 07/2013/TT-BXD ngày 15/5/2013 về hướng dẫn việc xác định các đối tượng được vay vốn hố trợ nhà ở theo nghị quyết số 02/NQ-CP ngày 07/01/2013 của Chinh phü [Circular No. 07/2013/TT-BXD dated 15 May 2013 guide the identification of beneficiaries of housing support loans under the Government's Resolution No. 02/NQ-CP dated 7 January 2013]. Retrieved May 20, 2019, from https://thuvienphapluat.vn/vanban/Tai-chinh-nha-nuoc/Thong-tu-07-2013-TT-BXD-huong-dan-xac-dinh-doi-tuong-dieukien-vay-ho-tro-nha-o-187671.aspx

Bộ xây dựng. (2014a). Nghị định 188/2013/NĐ-CP ngày 20/11/2013 về phát triển và quản lý nhà ở xã họi [Decree No. 188/2013/ND-CP dated 20 November 2013 on development and management of social housing]. Retrieved October 1, 2019, from https://thuvienphapluat.vn/van-ban/Bat-dong-san/Nghi-dinh-188-2013-ND-CP-phat-trienquan-ly-nha-o-xa-hoi-213910.aspx

Bộ xây dựng. (2014b). Thông tu số 08/2014/TT-BXD ngày 23/5/2014 của Bộ trưởng Bộ xây dụng về hướng dẫn thưc hiện một số nội dung của Nghị định số 188/2013/NĐ-CP ngày 20/11/2013 của Chính phủ về phát triển và quản lý nhà ở xã hội [Circular No. 08/2014/TTBXD dated 23 May 2014 of the Minister of Construction guiding the implementation of some contents of the Government's Decree No. 188/2013/ND-CP dated 20 November 2013 social housing development and management]. Retrieved October 2, 2019, from https://thuvienphapluat.vn/van-ban/Bat-dong-san/Thong-tu-08-2014-TT-BXD-huong-dan188-2013-ND-CP-phat-trien-quan-ly-nha-o-xa-hoi-232151.aspx?tab=4

Chính phủ. (2006). Nghị định 90/2006/NĐ-CP ngày 06/09/2006 về quy định chi tiết và hướng dẫn thi hành luật nhà ở [Decree No. 90/2006/ND-CP dated 06 September 2006 detailing and guiding the implementation of the housing law]. Retrieved October 3, 2019, from https://thuvienphapluat.vn/van-ban/Bat-dong-san/Nghi-dinh-90-2006-ND-CP-huong-dan-

Luat-Nha-o-14072.aspx

Chính phủ. (2010). Nghị định 71/2010/NĐ-CP ngày 23/06/2010 về quy định chi tiết và huớng dẫn thi hành luật nhà ở [Decree No. 71/2010/ND-CP dated 23 June 2010 detailing and guiding the implementation of the housing law]. Retrieved October 3, 2019, from https://m.thuvienphapluat.vn/van-ban/bat-dong-san/Nghi-dinh-71-2010-ND-CP-huong-danLuat-nha-o-107828.aspx

Chính phủ. (2015). Nghị định số 100/2015/NĐ-CP ngày 20/10/2015 về phát triển và quản lý nhà ở xã họi [Decree No. 100/2015/ND-CP dated 20 October 2015 on development and management of social housing]. Retrieved October 4, 2019, from https://thuvienphapluat.vn/van-ban/Bat-dong-san/Nghi-dinh-100-2015-ND-CP-phat-trienquan-ly-nha-o-xa-hoi-295027.aspx

Hiệp hội bất động sản TPHCM. (2018). Đề xuất co chế, chính sách phát triển nhà ở xã hội, nhà ở thuơng mại giá thấp phù hợp với điều kiện thực tiễn của thành phố Hồ Chí Minh [Proposing mechanisms and policies to develop social housing, low-cost commercial housing suitable to practical conditions of Ho Chi Minh City]. Retrieved October 6, 2019, from http://www.horea.org.vn/media/ftp/110.pdf

Ngân hàng nhà nước (NHNN). (2015). Thông tu số 25/2015/TT-NHNN ngày 9/12/2015 của Ngân hàng Nhà nước Việt Nam về hướng dẫn cho vay vốn uu đãi thực hiện chính sách nhà ở xã họi [Circular 25/2015/TT-NHNN dated 9 December 2019 of the State Bank of Vietnam on guidance on preferential loans for implementation of social housing policy]. Retrieved October 6, 2019, from https://thuvienphapluat.vn/van-ban/Dau-tu/Thong-tu-25-2015-TTNHNN-cho-vay-von-uu-dai-thuc-hien-chinh-sach-nha-o-xa-hoi-297871.aspx?tab=2 
Ngân hàng Chính sách xã hội. (2016). Văn bản số 2510/NHCS-TDSV ngày 26/07/2016 [Document No. 2510 / NHCS-TDSV dated July 26, 2016].

Nguyen, N. T. T. (2011). Hợp tác công tư phát triển thị trường nhà ở cho người thu nhập thấp tại thành phố Hồ Chí Minh [Public-private partnerships to develop a housing market for lowincome people in Ho Chi Minh City]. Tạp chí Phát triển Kinh tế, 20-28.

Quốc Hội. (1993). Luật đất đai [Land law]. Retrieved October 7, 2019, from https://thuvienphapluat.vn/van-ban/Bat-dong-san/Luat-Dat-dai-1993-24-L-CTN-38481.aspx

Quốc Hội. (2006). Luật Kinh doanh Bất động sản [Real estate Business law]. Retrieved October 8, 2019, from https://thuvienphapluat.vn/van-ban/Thuong-mai/Luat-kinh-doanh-bat-dong-san2006-63-2006-QH11-12982.aspx

Quốc hội. (2005). Luật nhà ỏ [Housing law]. Retrieved October 9, 2019, from https://thuvienphapluat.vn/van-ban/Bat-dong-san/Luat-nha-o-2005-56-2005-QH116918.aspx

Quốc hội. (2014). Luật nhà ở [Housing law]. Retrieved October 11, 2019, from https://thuvienphapluat.vn/van-ban/Bat-dong-san/Luat-Nha-o-2014-259721.aspx

Sở xây dựng thành phố Hồ Chí Minh, Đại học Việt Đức. (2018). Đề án phát triển thị trương bất động sản thành phố Hồ Chí Minh giai đoạn 2016-2020, Định hương đến năm 2015 và tầm nhì đến năm 2030 [Project to develop real estate market in Ho Chi Minh City for the period 2016-2020, Orientations to 2015 and a vision to 2030]. Ho Chi Minh, Vietnam: Sở xây dựng thành phố Hồ Chí Minh.

Thủ tướng chính phủ. (2009). Quyết định số 67/2009/QĐ-TTg ngày 24/4/2009 về ban hành một số cơ chế, chính sách phát triển nhà ở cho người có thu nhập thấp tại khu vực đô thị [Decision 67/2009/QD-TTg dated 24 April 2009 on the promulgation of a number of mechanisms and policies to develop housing for low-income people in urban areas]. Retrieved May 10, 2019, from https://thuvienphapluat.vn/van-ban/bat-dong-san/quyet-dinh-67-2009-qd-ttg-chinhsach-phat-trien-nha-o-nguoi-co-thu-nhap-thap-khu-vuc-do-thi-87579.aspx

Thủ tướng chính phủ. (2006). Quyết định 76/2004/QĐ-TTg ngày 06/5/2004 về phê duyệt dịnh huoóng phát triển nhà ở đến năm 2020 [Decision 76/2004/QD-TTg dated 06 May 2004 approving housing development orientation to 2020]. Retrieved May 15, 2019, from https://thuvienphapluat.vn/van-ban/Bat-dong-san/Quyet-dinh-76-2004-QD-TTg-dinh-huongphat-trien-nha-o-den-2020-52051.aspx

Tổng cục thống kê. (2017). Statistical yearbook of Viet Nam 2017. Retrieved May 18, 2019, from https://www.gso.gov.vn/wp-content/uploads/2019/10/Nien-giam-2017-pdf.pdf

Vo, H. T. M. (2011). Phát triển thị trường nhà ở cho người có thu nhập thấp [Develop a housing market for low-income people]. Tạp chí Ngân Hàng, 49-54. 